\title{
THE
}

\section{Factors Associated with Financial Independence of Young Adults}

Jing Jian Xiao

University of Rhode Island, xiao@uri.edu

Swarn Chatterjee

Jinhee Kim

Follow this and additional works at: https://digitalcommons.uri.edu/hdf_facpubs

The University of Rhode Island Faculty have made this article openly available.

Please let us know how Open Access to this research benefits you.

This is a pre-publication author manuscript of the final, published article.

Terms of Use

This article is made available under the terms and conditions applicable towards Open Access

Policy Articles, as set forth in our Terms of Use.

\section{Citation/Publisher Attribution}

Xiao, J. J., Chatterjee, S. and Kim, J. (2014), Financial independence of young adults. International Journal of Consumer Studies, 38: 394-403. doi: 10.1111/ijcs.12106

Available at: http://dx.doi.org/10.1111/ijcs.12106

This Article is brought to you for free and open access by the Human Development and Family Science at DigitalCommons@URI. It has been accepted for inclusion in Human Development and Family Science Faculty Publications by an authorized administrator of DigitalCommons@URI. For more information, please contact digitalcommons-group@uri.edu. 
Xiao, J. J., Chatterjee, S., \& Kim, J. (2014). Factors associated with financial independence of young adults. International Journal of Consumer Studies, 38, 394-403.

\title{
Factors Associated with Financial Independence of Young Adults
}

\author{
Jing Jian Xiao, Ph.D., Professor (Corresponding author) \\ Department of Human Development and Family Studies \\ University of Rhode Island \\ Email: xiao@uri.edu
}

Swarn Chatterjee, Ph.D., Associate Professor

Department of Housing and Consumer Economics

University of Georgia

Email: $\underline{\text { swarnc@gmail.com }}$

Jinhee Kim, Ph.D., Associate Professor

Department of Family Science

University of Maryland

Email: jinkim@umd.edu 


\title{
Factors Associated with Financial Independence of Young Adults
}

\begin{abstract}
Young adults are in an important transition period from financially depending on their parents to becoming financially independent. The purpose of this study was to identify factors associated with perceived financial independence among American young adults aged 18-23. Taking an interdisciplinary perspective, we hypothesized that major contributing factors of young adults' financial independence would include economic, psychological and family factors. Data were from two linked data sets, the 2009 Transition into Adulthood data set and its parental companion data set, the 2009 Panel Study of Income Dynamics, a nationally representative U.S. sample. Results indicated that economic factors, such as young adults' income, assets, work status, and educational attainment were positively associated with financial independence. Several psychological factors such as economic self-efficacy, money management ability, and problem-solving ability were also positively associated with financial independence. Family economic factors such as parental income, stock holding, and financial assistance decreased the level of young adults' financial independence. Additional analyses indicated that the level of financial independence of college graduates was higher than those who had never attended college or were currently in college, but did not differ from those who had dropped out of college. Common and different factors associated with young adults' financial independence were also identified among the four education groups. The findings of this study have implications for consumer educators to develop and implement targeted financial education programs for young adults aged 18-23 who differ by educational attainment.
\end{abstract}

Keywords: financial independence, educational attainment, self-efficacy, financial behavior, young adults, financial education 


\section{Introduction}

The financial independence of young adults is important for themselves, their parents, and society. Young adults consider financial independence to be one of the top criteria for entering adulthood (Arnett, 2000). No parents would like their children to rely on them for life. Financially independent young adults are necessary for the healthy development of a society. Recently the process of transition to adulthood has become lengthened and more complicated for young adults. Key milestones such as residential independence, completion of education, entering the workforce, marriage and having children have become more protracted and diverse (Furstenberg, Rumbaut and Settersten, 2005). With a longer period of transition to adulthood, many young adults rely on their parents and immediate families for financial assistance over an extended period of time. Researchers estimate that parents provide, on average, $\$ 38,000$ in material assistance such as housing, food, educational, or direct cash assistance during the transition period (Schoeni and Ross, 2005). Families spend approximately $10 \%$ of their annual income to support their young adult children of ages 18 to 21 (Settersten and Ray, 2010). During this prolonged and complex process, some young adults become more vulnerable as they do not receive the needed support from parents or other family members (Furstenberg et al., 2005).

One of the major reasons for young adults taking a longer time to become financially independent is the higher demand for training and education required by society. In the U.S., about half of young adults between the ages of 18 and 21 years attend college and only a quarter of adults age 24-35 become college graduates. The rest of the young adults either drop out of college or never attend college (Settersten and Ray, 2010). The association between educational attainment and transition to adulthood found in extant literature (Lee and Mortimer, 2009) 
suggests that educational attainment of young adults may also affect their financial independence.

The process of financial independence has become more complex in many developed countries. A recent study of British and Canadian youth found that the transition to adulthood and financial independence took longer under current socioeconomic conditions, which resulted in lower social status for the transitioning adults (Cote and Bynner, 2008). The study authors found that youth from disadvantaged and excluded groups in both countries were more vulnerable to this changing economic environment.

In this context, the UK has started a program called ConneXions that provides counselling services to youth from excluded populations (Cote and Bynner, 2008). Similarly, in another study Bynner and Parsons (2000) found that youth who dropped out early and did not participate in education, employment or training related programs were the least successful in dealing with this transition to adulthood and were more likely to develop mental, physical, and substance abuse related problems. Similarly, other studies have shown that encouraging Canadian youth to gain work experience through part-time jobs or internships when they were completing high school or college improved their marketability and allowed them smoother transitions to financially independent adulthood (Bynner, 1999; Hango and de Broucker, 2007).

As a result of this changing environment, it has therefore become more important for young adults to not only earn but also manage their finances carefully while they secure their socioeconomic stability as financially independent adults. Financial literacy is important in order to accomplish the goals that lead to the path of financial independence and for the financial wellbeing of young people as they transition toward adulthood (Chen and Volpe, 2002; Lusardi, Mitchell and Curto, 2010; Huston, 2012). High levels of debt, for instance from student loans 
and credit cards, could hinder young adults' financial independence. Identifying factors associated with financial independence of young adults in the United States will make it possible to compare the situation in this country with findings from extant research conducted in other countries facing a similar situation with an extended transition of their youth to adulthood and financial independence. The findings of this study will also inform the interested scholars, policy-makers and practitioners in designing helpful financial education programs for young adults who need the education on these topics as they transition to adulthood.

Research specifically on the financial independence of young adults is limited (Lee and Mortimer, 2009; Whittington and Peters, 1996). The purpose of this study is to identify factors associated with perceived financial independence of young adults using a nationally representative sample in the U.S. Further, we explore the association between financial independence and educational attainment status with additional analyses. The data used in the present study are from two linked data sets, the 2009 Transitioning into Adulthood (TA) and its parental companion data set, the 2009 Panel Study of Income Dynamics (PSID) in the U.S..

\section{Literature Review}

\section{Measures and Patterns of Financial Independence}

One early study defines the child to be financially independent if she or he resides in a group living arrangement, alone in a noninstitutional environment, joins the military, or leaves the home for marriage. Children living in institutional housing such as at college or children who have income but still live with parents are not considered financially independent (Whittington and Peters, 1996).Using data from the Panel Study of Income Dynamics, the median age of independence was 19 years for men and 21 years for women (Whittington and Peters, 1996). The likelihood of independence rose for women until age 22, fell briefly, and spiked again at age 26 . 
For men, the likelihood rose until age 21, fell slightly, and then increased again until age 25 (Whittington and Peters, 1996).

A more recent study measured young adults' financial independence by examining the percentage of their living expenses that came from either their own earnings or savings or from their spouse or partner's earnings and/or savings at ages 23-24 (Lee and Mortimer, 2009). Among a sample of young adults in this longitudinal study in Minnesota, at ages 23-24, a little less than three-quarters $(73.7 \%)$ of the respondents reported being financially independent and able to cover their own expenses (Lee and Mortimer, 2009).

\section{Factors Associated with Financial Independence}

Economic factors such as wages for both male and female children or welfare income receipts for female children have been found to be important determinants of financial dependence (Whittington and Peters, 1996). Living with parents has also been shown as an indicator of financial dependence. U.S. census data from 1960-2007 showed that comparing changes in economic conditions across states to changes in living arrangements, several factors led to increases in the number of young adults living with their parents, including fewer jobs, low wages, and high rental costs (Matsudaira, 2010). According to a Dutch study on financial independence of young adults, the timing of leaving home was associated with the perceived costs and benefits of leaving home and with the perceived housing market situation (Billari and Liefbroer, 2007).

Economic self-efficacy has also been considered an important factor for young adults’ financial independence. This factor has been measured by combining information from questions concerning future expectations, job, and home ownership. In a panel study, this variable was significantly associated with financial independence in a model with only demographic control 
variables (Lee and Mortimer, 2009). However, after attainment variables such as current school enrollment, employment status, marital status, parenthood, educational attainment, and income were added to the model, its effect disappeared (Lee and Mortimer, 2009).

Other psychological factors may also influence young people's financial independence. Research on saving behavior among young Canadians aged 12-24 concluded that peer groups identified as adult - or achievement oriented were more likely to save money, especially for future schooling (Erskine et al., 2006). Gender and racial differences have also been found in young adults' financial independence. After analyzing the PSID data among women and men separately, researchers found that determinants of financial independence were different (Whittington and Peters, 1996). Cross-national comparisons have shown that across seven industrialized nations_-France, Germany, Italy, Netherlands, Sweden, UK, and the United States_-young women were less able than young men to become economically independent through market work alone (Smeeding and Phillips, 2002). The authors however found that compared to the other nations, the Italian young men did not earn enough to become financially independent as quickly; conversely, the Dutch men become financially independent relatively faster than the youth from the other countries included in their study. This study also found that the earnings of young Italian women were not enough to make them financially independent. Additionally, the earnings of women in Netherlands and Germany increased between 23-27 years of age but fell after that. Overall, the earnings of women in Sweden, UK, and the United States remained steady across time. Using data from PSID, researchers have compared 1950sand 1960s-born cohorts regarding work and income and found significant changes among women (Corcoran and Matsudaira, 2005). Saving behaviors, an important factor for financial independence, were different between white and black young adults (Friedline and Elliott, 2011). 
Leaving home is an important topic in the research literature on young adults. Factors associated with leaving home are relevant to factors influencing financial independence. For young adults, leaving home serves two primary purposes: going to college or living independently. The first option is a means of human capital investment that enhances the likelihood of financial independence at a future date, while the second option is an indicator of current financial independence. Economic factors such as housing prices and personal income are important for the decision to leave or to return to parental homes (Ermisch, 1999). Previous research has documented differences in leaving home by nation, gender and ethnicity (Iacovou, 2002; Blaauboer and Mulder, 2010; Zorlu and Mulder, 2011).

\section{Parental Influence on Financial Independence}

Parents play an important role in children's financial socialization (Kim, LaTaillade and Kim, 2011). Young adults' financial independence has been associated with the economic status of their parents. The parental income decreased the likelihood of independence for women but did not show any effects for men (Whittington and Peters, 1996). Cross-national comparisons indicated that family financial support, the provision of housing, and caring labor were clearly important to the economic well-being of young adults (Smeeding and Phillips, 2002). Young adults who were raised in homes with more wealth at one point in their early childhood were more likely to have positive outcomes, such as graduating from high school, enrolling in college, and establishing their own independent checking and savings accounts (Destin, 2009), all of which are necessary conditions for financial independence.

Parental economic behaviors may be followed by children. A young family's likelihood of owning transaction accounts and stocks has been found to be affected by whether the parents hold these financial assets (Chiteji and Stafford, 1999). Data from Canada has shown that young 
adults who reported that their parents and friends were heavy credit users were more likely to have positive attitudes towards credit (Lachance, 2012).

Parenting style may affect financial independence of young adults. Previous research showed that direct communication with parents about work fostered the development of economic self-efficacy. In turn, economic self-efficacy fostered achievement during the transition to adulthood (e.g., educational achievement, employment status, and income attainment), which, in turn, affected financial independence in early adulthood (Lee and Mortimer, 2009). Resilience to the difficult transition from adolescence to early adulthood was especially fostered by nurturant-involved parenting and by less angry or hostile parenting (Conger and Conger, 2002).

Research on young adults' financial behaviors has suggested that parental influences may have positive impacts on their future financial independence. Research among youth aged 15-21 found that parental behavior (such as discussing financial matters with children) and parental orientations (conscientiousness, future orientation) had a weak but clear impact on children's current and later economic behavior (Webley and Nyhus, 2006). Research among first-year college students showed that parental financial socialization was related to financial learning, which in turn was related to financial attitudes and subsequently to financial behavior (Shim et al., 2010). Research among college students showed that parental hands-on mentoring of financial skills was most strongly related to lower levels of credit card debt. Having parents who avoided talking about finances predicted problematic credit card use. Students' beliefs that their parents would bail them out of debt were related to lower levels of debt (Norvilitis and MacLean, 2010). For college students who relied on their parents or used a combination of resources to repay their debt, higher financial responsibility levels were associated with lower compulsive 
buying practices (Brougham et al., 2011). A study on investor behavior found that parents emerged as a relevant socialization agent of investors, influencing investment regularity and household net worth above and beyond other factors (Hira, Sabri and Loibl, 2013).

For many young adults, leaving home is an indicator of financial independence or a transition to financial independence. Leaving home has been strongly related to parental economic conditions. Research has shown the effects of parental resources differed depending on the route out of the home under consideration (Avery, Goldscheider, and Speare, 1992). The likelihood of returning home increased with parental income (Mulder and Clarke, 2002). Poverty status was related to home leaving patterns (DeMarco and Berzin, 2008). Parenting styles were also associated with leaving home (Billari and Liefbroer, 2007; Blaauboer and Mulder, 2010).

\section{Summary of the Literature}

Young adults' financial independence is important not only for themselves and their families but also for the healthy development of the economy. The existing literature suggests economic, psychological, and demographic differences in young adults' financial independence. Family factors such as parental socioeconomic conditions and parenting styles affect the degree of young adults' financial independence. Unlike previous direct research on young adults' financial independence (Whittington and Peters, 1996; Lee and Mortimer, 2009), this study focused on perceived financial independence. We examined factors associated with financial independence of young adults as a whole and by educational attainment statuses.

\section{Theoretical Framework and Hypotheses}

\section{Theoretical Framework}

Young adult's financial independence can be viewed from economic and sociopsychological perspectives. Based on work by McElroy (1985) and Hill and Hill (1974), 
Whittington and Peters (1996) have developed an economic framework to view the decisionmaking of a young adult's financial independence that is characterized as living away from parents and taking care of their own finances. Based on their framework, it is optimal for the child to remain dependent on the parents as long as her (or his) maximum willingness to pay for the benefits from the arrangement is greater than the parents' minimum willingness to accept having the child as a dependent. The maximum the child is willing to pay is equal to the difference between the utility she receives from being dependent on her parents and the utility she would receive from being financially independent. The child's demand for privacy is assumed to be a normal good in economic term, in which the demand for privacy rises with income and decreases with the costs of living alone. In addition, demand for privacy may increase with age.

The effect of parental economic resources is more complicated. If parents care about the child's well-being and if the well-being is a normal good, parental income should be negatively associated with the child's independence, as parents with higher incomes would discourage the child to live alone financially and physically. On the other hand, if parents care about their own privacy, the relationship between parental income and child's independence may be positive. From a human developmental perspective, parents may consider the child's age to determine whether the child ought to leave home and be financially independent. Parents may prefer that younger children remain dependent so that the parents can maintain some control over their behaviors (Avery, et al., 1992). Thus, the effect of parental income on child's independence cannot be straightforwardly predicted based on theory and therefore needs to be determined empirically. 
Lee and Mortimer (2009) view this topic from a socio-psychological perspective. They believe that two major factors determining young adults' financial independence are economic self-efficacy and the family communication process. Economic self-efficacy is derived from a major psychological concept of self-efficacy (Bandura, 1977). Lee and Mortimer (2009) argue that economic self-efficacy appears to be critical in fostering achievement-relevant behaviors. For example, youth who think they will be successful in achieving their goals in the economic realm are likely to be more persistent in their preparation and striving for post-secondary education. They also assert that family socialization, particularly communication about work and money, is an important factor in the development of economic self-efficacy, which leads to a greater likelihood of being financially independent during young adulthood. Family communication can occur in various ways, both overtly through social interaction and covertly though role modeling and reinforcement of behaviors (Moschis, 1985). Children may follow their parents to perform similar financial behaviors. They may also learn financial knowledge and skills when actively communicating with their parents. During these family communication processes, they increase the level of economic self-efficacy that contributes to their financial independence (Shim et al., 2010; Kim et al., 2011).

Among young adults aged 18-23, educational attainment statuses may affect determinants of their financial independence. Previous research has suggested that education may affect household financial obligation burden (Hanna, Yuh and Chatterjee, 2012) and financial difficulty status (Patel, Balmer and Pleasence, 2012). In this study, educational attainment had four categories: having never attended college, been in college, dropped out of college, and graduated from college. College students may achieve a higher level of financial independence after graduation but they may have the lowest level of financial independence when they are in 
college. If attending college is considered as a form of human capital investment, we expected that college graduates would have the highest level of financial independence compared to other educational attainment statuses, given other factors.

\section{Hypotheses}

Based on the above discussions, we assumed that young adult's financial independence was determined by both children and family related factors and these factors included both economic and socio-psychological characteristics. Specifically, we proposed following hypotheses:

H1: Young adults' economic resources are positively associated with their perceived financial independence.

H2: The young adults' economic self-efficacy is positively associated with their perceived financial independence.

H3: Parental economic resources are associated with young adults' perceived financial independence.

H4: Parental communications with children are positively associated with young adults' perceived financial independence.

H5: Among four education attainment groups, college graduates perceive the highest level of financial independence.

\section{Method}

\section{Data}

This study drew information on young adults aged 18 to 25 from two linked data sets, the 2009 Transition to Adulthood (TA) and its parental companion data set, the 2009 Panel Study of Income Dynamics (PSID). The PSID is a longitudinal study of a nationally representative sample 
of U.S. residents and TA includes information of children whose parents are included in PSID. For the past approximately four decades, the study has collected annual data from these individuals about their demographic, economic, and psychological characteristics. The TA supplement includes 1,432 young adults aged 18-23.

\section{Dependent Variable}

The dependent variable used for empirically testing our hypotheses was perceived financial independence. Financial independence was measured based on a Likert type scale, where 1 referred to the lowest level and 5 the highest level of financial independence. This scale was publicly available in the TA supplement of PSID. The scale was constructed based on the average of respondents' responses to the following questions: How much responsibility do you have for earning own living? How much responsibility do you have for paying own rent? How much responsibility do you have for paying own bills? How much responsibility do you have for managing own money?, where 1 referred to the minimum and 5 referred to the maximum amount of responsibility across these Likert type scales. The computed Chronbach's alpha for the scale was 0.75 .

\section{Independent Variables}

Child characteristics. The respondents' age was a continuous variable. Gender was a binary variable with 1 indicating female and 0 male. Two dummy variables were used to indicate whether or not the respondent had a part-time job or a full-time job, and the omitted variable comprised of respondents who did not work. The race/ethnicity variable was coded as 1 if the respondent was white and 0 otherwise. Similarly, the educational attainment of the respondents were categorized into four binary variables: never attended college, dropped out of college, currently in college, and graduated from college. Young adults' log income and assets 
were also included in the model. The log form was used to suppress the outlier effects. Other demographic variables were living with parents, region of residence (northeast, north central, south, and west), whether residing in a rural area, and marital status.

The economic self-efficacy scale was constructed from the following items in the data set: likelihood of a job that pays well, likelihood of supporting family, and the likelihood of being laid off from a job, which was similar to the economic self-efficacy factor used in Lee and Mortimer's study (2009). The last variable was reverse coded before the scale was constructed. Two other perception variables such as the respondents' perceived money management ability and problem solving ability were also included in the model.

Parental characteristics. This study included several parental communication-related factors such as the respondents' perceived levels of communication with their mother and father, and their perceived closeness to their mother and father. It also included a variable on whether the respondents received financial help from their families. The amount of family financial help received was represented in the model in log form. Other resource-related variables included parental education, income, assets, debt, food stamp receiving status, and stock ownership. These variables were taken from the 2009 PSID data set. Log transformed values of income, assets, and debt were used to control non-normality.

\section{Data Analyses}

The empirical analyses comprised univariate, bivariate, and multivariate analyses. To empirically test the hypotheses of this study, we utilized an ordered logit model because the dependent variable, educational attainment, was an ordinal one.

\section{Results}

\section{Descriptive Statistics}


The descriptive statistics of the sample are shown in Table 1. The results indicate that the average age of the transitioning adults was 21 years. Approximately $53 \%$ of the respondents were women. Regarding educational attainment, $41 \%$ of the respondents were in college, $9 \%$ had graduated, 33\% never attended college, and 17\% had dropped out of college. Fifty-five percent of the respondents were employed and $46 \%$ of the respondents reported living with their parents. The mean self-reported economic self-efficacy score was 27.8 out of a range of 12 to 34 . The self-reported ability to manage money had a mean score of 9 on a scale of $1-14$, whereas the selfreported ability for problem solving had a mean score of 6 on a scale of 1-7. On a scale of 1-5 for perceived financial independence, the mean was 4.

\section{Results from Bivariate Analyses of Financial Independence By Education Attainment}

The results of the bivariate analyses, presented in Table 2, indicate that the level of perceived financial independence was the highest among those who had graduated from college. The pairwise tests demonstrate that respondents who had graduated from college had significantly higher levels of perceived financial independence than those in other educational attainment categories, with the exception of the college dropouts. Respondents that were currently attending college had the lowest level of perceived financial independence among all groups.

\section{Results of Logit Regressions on Financial Independence}

Table 3 presents the ordered logit regression results. A number of economic factors were found to be significant predictors of perceived financial independence of young adults, such as young adult's income, assets, work status, and educational attainment (an economic term for human capital investment). For example, compared to the reference group (never attended college), those who had graduated from college were likely to have a higher level of financial 
independence while those who were still in college had a lower level of financial independence. Economic self-efficacy was also positively associated with financial dependence. Other child characteristics (control factors) positively contributing to financial dependence include money management ability, problem solving ability, being male, being older, not living with parents, and/or living in a rural area or the west region.

Among parental communication factors, closeness to the father was positively associated with financial independence of transitioning adults. An examination of the association between parental socioeconomic characteristics and perceived financial independence revealed that mother's educational attainment was positively associated with young adults' perceived financial independence. Conversely, receiving financial help from family, parental stock ownership, and the amount of family income were negatively associated with the level of perceived financial independence of transitioning adults.

\section{Results of Logit Regressions by Educational Attainment Categories}

Table 4 presents determinants of financial independence separately for young adults who had been in college, never attended college, dropped out of college, and graduated from college. Three significant predictors are found in all four groups in which working and living in a rural area were associated with higher levels and living with parents was associated with lower levels of financial independence. Four variables - young adult's age, gender, marital status, and assets - significantly affected three of the four education groups. Four variables-young adult's living region, money management ability, parental stock holding, and financial support—were associated with only two of the four education groups. Nine variables showed their effects on only one of the four education groups (4 in "in college," 3 in "college graduate," 2 in "college 
dropout"). Thus, both common and different determinants of financial independence were found among young adults with different educational attainments.

\section{Discussions}

In this study, using data from the 2009 Transition to Adulthoods and its parental companion data set, Panel Study of Income Dynamics, we calculated the average score of financial independence among American young adults aged 18-23. The score was 4 out of a 5point scale, implying a typical young adult in this age group was still in the lifecycle stage transitioning from financial dependence to independence. The result is compatible with previous research. An earlier study using the PSID data indicated that the peak age of full financial independence was in the range of 25-26 (Whittington and Peters, 1996). A recent study using a state sample showed that until age 26, a little less than three-fourths of young adults had reached full financial independence (Lee and Mortimer, 2009).

Consistent with hypothesis 1 , personal economic resources were positively associated with financial independence. Young adults who were employed were more likely to report financial independence as indicated by the results with the whole sample (Table 3) and with the educational attainment subsamples (Table 4). Several other indicators showing higher levels of economic resources, such as personal income and assets, were associated with higher scores of financial independence in the main sample and subsamples even though the results from the main sample were stronger than those in the subsamples.

Economic self-efficacy is an important factor for young adults' financial independence, according to previous research (Lee and Mortimer, 2009). Hypothesis 2 was supported by the results in which a higher level of economic self-efficacy was associated with a higher level of financial independence in the main sample. In the four subsamples, $\mathrm{H} 2$ was supported by the 
results from two groups: having never attended college and having graduated from the college. Interestingly, two related ability factors, money management and problem solving abilities, showed positive effects on financial independence in the main sample. Their effects on the four subsamples varied. The results suggested enhancing all these abilities would increase young adults' financial independence.

According to our discussion for hypothesis 3, we cannot theoretically decide the direction of effects of parental economic resources on child's financial independence. If parents care more about children's well-being and if they have more economic resources, they should be less likely to let their children be financially independent. However, if they also care about their own privacy and social norms about financial independence at a certain age or circumstances, they may be more likely to encourage their children to be financially independent. Then, parental economic factors should be age specific and empirically determined. Among the age group of 18-23 in our study, we found that several parental resource factors did not show effects on children's financial independence in the main sample, such as parental wealth and debt. Family financial help, parental income, and parental stock ownership showed negative effects implying that young adults with parents having higher resource levels were less likely to report financial independence. These patterns were also shown in the four subsamples. For example, in the attending college group, parental income, assets, stock ownership, and family financial assistance showed negative effects on financial independence. In the graduating from college group, the effects of parental income and asset were negative. In the college dropout group, parents receiving food stamps had a positive effect while family financial assistance had a negative effect on young adults' perceived financial independence. These results suggest that young adults with more affluent parents were less likely to report financial independence. 
Conversely, young adults from less affluent families may need to be financial independent sooner than their richer counterparts.

Hypothesis 4 stated that more parental communication would increase children's financial independence. This effect was not very strong based on our findings. According to the results from the main sample, among four parental socialization variables, only closeness to fathers had a positive effect. These results suggest that parental communication may not be strong as indicated by previous research (Lee and Mortimer, 2009) regarding financial independence. Also, available parental communication variables in the data were not specific about financial independence. Parental communication variables were not significant among college dropouts and those who never attended college. Parental economic factors may be more important than parental socio-psychological factors in this regard. However, none of communication or economic variables of parents were found to be significant among those who never attend college.

Our findings support Hypothesis 5 that college graduates would have the highest level of financial independence. After controlling for several sets of child and parental variables, college graduates had significantly higher scores of financial independence than those who had never attended college. Young adults who were attending college had the lowest level of financial independence compared to the reference category, having never attended college. Interestingly, college dropouts were not that different from those who had never attended college in terms of financial independence. Results from the four subsamples in Table 4 show different factors that affect financial independence of these young adults with different educational attainments. For example, both personal income and assets affected financial independence among the "in college" group, but only one of these factors affected financial independence in the other three 
groups. Effects of three ability factors on financial independence in the four subsamples were different too. Effects of parental economic resource and communication variables varied among four groups.

\section{Implications for Consumer Education}

Our findings have several implications for consumer education. The knowledge about the average scores of and factors associated with perceived financial independence produced by this study can be used in financial education programs for young adults. The results will help young adults understand their own status in terms of financial transition and work hard to move in the right direction to achieve their financial independence fully by studying harder, looking for jobs

more actively, and communicating with parents more effectively. Our findings suggest that economic factors are more important to financial independence than other factors. For young adults in college, college may be the best opportunity for them to accumulate marketable human capital that will enable them to smoothly move into a job they want and achieve financial independence promptly after graduation. Our findings also show that young adults' economic self-efficacy, money management ability, and problem-solving ability are important to financial independence. Consumer educators should consider these factors and design, develop, and implement effective consumer education programs to help these young adults enhance skills in these areas besides teaching them the contents of personal finance.

The different determinants of financial independence among young adults in different education groups can also be leveraged by consumer educators to improve financial education programs to meet young people's special needs. For example, regarding the set of psychological variables, for young adults who are still in college, education emphasizing money management ability can enhance their sense of financial independence. For college graduates, education about 
economic self-efficacy is more important. For those who have never attended college, education on both economic self-efficacy and money management ability will be helpful. Programs for college dropouts could focus on enhancing their problem-solving ability.

To provide effective financial education programs for young adults with different educational attainments, many good suggestions provided by consumer researchers can be utilized. For example, financial education can be integrated into general education programs for young adults in college (Crain and Ragan, 2012). For young adults who have never attended college, dropped out of college, or graduated from college, effective financial education programs should adopt inclusive, culturally responsive pedagogies (Taylor, Tisdell and Forté, 2012). To educate young adults with various educational attainments to achieve the goal of full financial independence and sustainable financial well-being, teaching strategies should be carefully designed (Baumann and Hall, 2012), financial responsibility values should be emphasized (Hira, 2012), and psychological biases and limitations should be addressed in the financial education programs (West, 2012). 


\section{References}

Arnett, J. J. (2000) Emerging adulthood: a theory of development from the late teens through the twenties. American Psychologist, 55, 469-480.

Avery, R., Goldscheider, G. \& Speare, A. Jr. (1992) Feathered nest/gilded cage: parental income and leaving home in the transition to adulthood. Demography, 29, 375-388.

Bandura, A. (1997) Self-Efficacy: The Exercise of Control. Freeman, New York.

Baumann, C. \& Hall, T. (2012) Getting Cinderella to the ball: putting education at the heart of financial education. International Journal of Consumer Studies, 36, 508-514.

Billari, F. C. \& Liefbroer, A. C. (2007) Should I stay or should I go? the impact of age norms on leaving home. Demography, 44, 181-98.

Blaauboer, M. \& Mulder, C. H. (2010) Gender differences in the impact of family background on leaving the parental home. Journal of Housing and the Built Environment, 25, 53-71.

Brougham, R. R., Jacobs-Lawson, J. M., Hershey, D. A. \& Trujillo, K.M. (2011) Who pays your debt? an important question for understanding compulsive buying among American college students. International Journal of Consumer Studies, 35, 79-85.

Bynner, J. \& Parsons, S. (2002). Social exclusion and the transition from school to work: the case of young people not in education, employment or training (NEET). Journal of Vocational Behaviour, 60, 289-309.

Bynner, J. (1999). New routes to employment: integration and exclusion. In From Education to Work: Cross-National Perspectives (ed. by W. R. Heinz),pp.65-86. Cambridge University Press, Cambridge, UK.

Chen, H. \& Volpe, R. P. (2002) Gender differences in personal financial literacy among college students. Financial Services Review, 11, 107-128. 
Chiteji, N. S. \& Stafford, F. P. (1999) Portfolio choices of parents and their children as young adults: asset accumulation by African-American families. The American Economic Review, 89, 377-380.

Conger, R. D. \& Conger, K. J. (2002) Resilience in Midwestern families: selected findings from the first decade of a prospective longitudinal study. Journal of Marriage and the Family, 64, 361-373.

Cote, J. \& Bynner, J. (2008). Changes in the transition to adulthood in the UK and Canada: the role of structure and agency in emerging adulthood. Journal of Youth Studies, 11, 251-268.

Corcoran, M. \& Matsudaira, J. (2005) Is it getting harder to get ahead? economic attainment in early adulthood for two cohorts. In On the Frontier of Adulthood: Theory, Research, and Public Policy (ed. by R. A. Settersten, Jr., F. F. Furstenberg, Jr. \& R. G. Rumbaut), pp. 356-395. University of Chicago Press, Chicago, IL.

Crain, S. J. \& Ragan, K. P. (2012) Designing a financial literacy course for a liberal arts curriculum. International Journal of Consumer Studies, 36, 515-522.

DeMarco, A. C. \& Berzin, S. C. (2008) The influence of family economic status on homeleaving patterns during emerging adulthood. Families in Society: The Journal of Contemporary Social Services, 89, 208-218.

Destin, M. (2009) Assets, inequality, and the transition to adulthood: an analysis of the panel study of income dynamics. Issue Brief. Initiative on Financial Security, New York.

Erskine, M., Kier, C., Leung, A. \& Sproule, R. (2006) Peer crowds, work experience, and financial saving behaviour of young Canadians. Journal of Economic Psychology, 27, 262-284. 
Ermisch, J. (1999) Price, parents, and young people's household formation. Journal of Urban Economics, 45, 47-71.

Friedline, T. L. \& Elliott, W. (2011) Predicting savings for white and black young adults: an early look at racial disparities in savings and the potential role of children's development accounts (CDAs). Race and Social Problems, 3, 99-118.

Furstenberg, F. F., Rumbaut, R. G. \& Settersten, R. A. (2005) On the frontier of adulthood: emerging themes and new directions. In On the Frontier of Adulthood: Theory, Research, and Public Policy (ed. by R. A. Settersten, Jr., F. F. Furstenberg Jr. \& R. G. Rumbaut), pp. 3-28. The University of Chicago Press, Chicago, IL.

Hango, D. \& de Broucker, P. (2007). Education-to-labour market pathways of Canadian youth: findings from the Youth in Transition Survey. Statistics Canada, Culture, Tourism and the Centre for Education Statistics Research Papers, Ottawa.

Hanna, S. D., Yuh, Y. \& Chatterjee, S. (2012) The increasing financial obligations burden of US households: who is affected? International Journal of Consumer Studies, 36, 588-594.

Hill, D. H. \& Hill, M.S. (1974) Older children and splitting off. In Five Thousand American Families: Patterns of Economic Progress 4 (ed. by G. J. Duncan \& J. N. Morgan), pp. 117-53. Institute for Social Research, University of Michigan, Ann Arbor.

Hira, T. K. (2012) Promoting sustainable financial behavior: implications for education and research. International Journal of Consumer Studies, 36, 502-507.

Hira, T. K., Sabri, M. F. \& Loibl, C. (2013) Financial socialization's impact on investment orientation and household net worth. International Journal of Consumer Studies, 37, 2935. 
Huston, S. J. (2012) Financial literacy and the cost of borrowing. International Journal of Consumer Studies, 36, 566-572.

Iacovou, M. (2002) Regional differences in the transition to adulthood. Annals of the American Academy of Political and Social Science, 580, 40-69.

Kim, J., LaTaillade, J. \& Kim, H. (2011) Family processes and children's financial socialization. Journal of Family and Economic Issues, 32, 668-679.

Lachance, M. J. (2012) Young adults' attitudes towards credit. International Journal of Consumer Studies, 36, 539-548.

Lee, J. C. \& Mortimer, J. T. (2009) Family socialization, economic self-efficacy, and the attainment of financial independence in early adulthood. Longitudinal and Life Course Studies, 1, 45-62.

Lusardi, A., Mitchell, O. S. \& Curto, V. (2010) Financial literacy among the young. Journal of Consumer Affairs, 44, 358-380.

Matsudaira, J. D. (2010) Economic conditions and the cyclical and secular changes in parental coresidence among young adults: 1960 to 2007. Working paper. Cornell University, Ithaca, NY.

McElroy, M. B. (1985) The joint determination of household work and market work: the case of young men. Journal of Labor Economics, 3, 293-316.

Moschis, G. P. (1985) The role of family communication in consumer socialization of children and adolescents. Journal of Consumer Research, 11, 898-913.

Mulder, C. H. \& Clarke, W.A. (2002) Leaving home for college and gaining independence. Environment and Planning, 34, 981-999. 
Norvilitis, J. M. \& MacLean, M. G. (2010) The role of parents in college students' financial behaviors and attitudes. Journal of Economic Psychology, 31, 55-63.

Patel, A., Balmer, N. J. \& Pleasence, P. (2012) Debt and disadvantage: the experience of unmanageable debt and financial difficulty in England and Wales. International Journal of Consumer Studies, 36, 556-565.

Schoeni, R. F. \& Ross, K. E. (2005) Material assistance from families during the transition to adulthood. In On the Frontier of Adulthood: Theory, Research, and Public Policy (ed. by R. A. Settersten, F. F. Furstenberg Jr. \& R. G. Rumbaut), pp. 396-416. The University of Chicago Press, Chicago, IL.

Settersten, Jr., R.A. \& Ray, B. (2010) What's going on with young people today? the long and twisting path to adulthood. The Future of Children, 20, 19-41.

Shim, S., Barber, B., Card, N., Xiao, J. J. \& Serido, J. (2010). Financial socialization of first-year college students: the roles of parents, work, and education. Journal of Youth and Adolescence. 39, 1457-1470.

Smeeding, T. M. \& Phillips, K. R. (2002) Cross-national differences in employment and financial independence. Annals of the American Academy of Political and Social Science, 580, 103-133.

Taylor, E. W., Tisdell, E. J. \& Forté, K. S. (2012) Teaching financial literacy: a survey of community-based educators. International Journal of Consumer Studies, 36, 531-538.

Webley, P. \& Nyhus, E. K. (2006) Parent's influence on children's future orientation and saving. Journal of Economic Psychology, 27, 140-164. 
West, J. (2012) Financial literacy education and behavior unhinged: combating bias and poor product design. International Journal of Consumer Studies, 36, 523-530.

Whittington, L. A. \& Peters, E. H. (1996) Economic incentives for financial and residential independence. Demography, 33, 82-97.

Zorlu, A. \& Mulder, C. H. (2011) Ethnic differences in leaving home: timing and pathways. Demography, 48, 49-72. 
Table 1: Descriptive Statistics of the Sample (N=1432)

\begin{tabular}{|c|c|c|c|c|c|c|}
\hline & & Percent & Mean & SD & Min & Max \\
\hline \multirow[t]{21}{*}{ Child characteristics } & Age & & 20.943 & 2.209 & 18 & 25 \\
\hline & Female & $53 \%$ & & & 0 & 1 \\
\hline & White & $48 \%$ & & & 0 & 1 \\
\hline & Log personal income & & 4.339 & 4.364 & 0 & 11.918 \\
\hline & Log personal assets & & 5.27 & 4.147 & 0 & 18.516 \\
\hline & Live with parents & $46 \%$ & & & 0 & 1 \\
\hline & SAT math score & & 559 & 140 & 200 & 800 \\
\hline & South & $45 \%$ & & & 0 & 1 \\
\hline & West & $18 \%$ & & & 0 & 1 \\
\hline & Northeast & $12 \%$ & & & 0 & 1 \\
\hline & North central & $24 \%$ & & & 0 & 1 \\
\hline & Rural & $23 \%$ & & & 0 & 1 \\
\hline & Employed & $55 \%$ & & & 0 & 1 \\
\hline & Not married & $91 \%$ & & & 0 & 1 \\
\hline & Never attend college & $33 \%$ & & & 0 & 1 \\
\hline & In college & $41 \%$ & & & 0 & 1 \\
\hline & College dropout & $17 \%$ & & & 0 & 1 \\
\hline & College graduate & $9 \%$ & & & 0 & 1 \\
\hline & Economic self-efficacy & & 27.776 & 4.062 & 12 & 34 \\
\hline & Money management & & 9.225 & 3.374 & 1 & 14 \\
\hline & Problem solving & & 5.96 & 0.875 & 1 & 7 \\
\hline \multirow{4}{*}{$\begin{array}{l}\text { Parental } \\
\text { communication }\end{array}$} & Close to mother & & 5.959 & 1.67 & 0 & 7 \\
\hline & Close to father & & 4.768 & 2.322 & 0 & 7 \\
\hline & Father communication & & 13.037 & 7.202 & 0 & 36 \\
\hline & $\begin{array}{l}\text { Mother } \\
\text { communication }\end{array}$ & & 17.692 & 6.912 & 0 & 28 \\
\hline \multirow{8}{*}{$\begin{array}{l}\text { Parental } \\
\text { socioeconomic }\end{array}$} & Mother education & & 3.601 & 2.26 & 0 & 8 \\
\hline & Father education & & 3.365 & 2.429 & 0 & 8 \\
\hline & Log Fam. Fin help & & 5.092 & 3.083 & 0 & 12.153 \\
\hline & Parental stock status & & 0.118 & & 0 & 1 \\
\hline & Log parental assets & & 7.903 & 5.014 & 0 & 16.6 \\
\hline & Log parental debt & & -0.801 & 1.903 & 0 & 8.006 \\
\hline & Food stamp participation & & 0.164 & & 0 & 1 \\
\hline & Log family income & & 10.749 & 1.058 & 5.298 & 14.546 \\
\hline Dependent variable & $\begin{array}{l}\text { Financial } \\
\text { Independence }\end{array}$ & & 4.006 & 1.204 & 1 & 5 \\
\hline
\end{tabular}




Table 2: Pairwise Comparison of Difference in Means of Perceived Financial Independence by Education

\begin{tabular}{|c|c|c|c|c|c|c|}
\hline & & & \multicolumn{4}{|c|}{$\begin{array}{l}\text { Perceived Financial Independence } \\
\text { (1=Min; 5=Max) }\end{array}$} \\
\hline Never attended & & & \multicolumn{4}{|c|}{4.127} \\
\hline In college & & & \multicolumn{4}{|c|}{3.626} \\
\hline Dropped out & & & \multicolumn{4}{|c|}{4.424} \\
\hline Graduated & & & \multicolumn{4}{|c|}{4.462} \\
\hline Group 1 & & Group 2 & $\begin{array}{l}\text { Diff in } \\
\text { Means }\end{array}$ & SD & $\mathrm{t}$ & $\mathrm{p}$ \\
\hline College dropout & vs & Never attended & 0.297 & 0.087 & 3.405 & $* * *$ \\
\hline In college & vs & Never attended & -0.501 & 0.069 & 6.912 & $* * *$ \\
\hline Graduated & vs & Never attended & 0.334 & 0.109 & 3.067 & $* * *$ \\
\hline In college & vs & College dropout & -0.798 & 0.084 & 6.965 & $* * *$ \\
\hline Graduated & vs & College dropout & 0.038 & 0.120 & 0.373 & \\
\hline Graduated & vs & In college & 0.836 & 0.107 & 7.791 & $* * *$ \\
\hline
\end{tabular}


Table 3: Determinants of Financial Independence: Logit Regression Results

\begin{tabular}{|c|c|c|c|c|}
\hline Category & Variable & $\begin{array}{c}\text { Coefficient } \\
\text { Estimate }(\beta)\end{array}$ & $\mathrm{SD}$ & $\mathrm{p}$ \\
\hline \multirow[t]{19}{*}{ Child characteristics } & Age & 0.186 & 0.028 & $* * *$ \\
\hline & Female & -0.193 & 0.087 & $* * *$ \\
\hline & White & 0.066 & 0.134 & \\
\hline & Log personal income & 0.176 & 0.024 & $* * *$ \\
\hline & Log personal assets & 0.133 & 0.037 & $* * *$ \\
\hline & Live with parents & -0.713 & 0.204 & $* * *$ \\
\hline & SAT Math & 0.037 & 0.031 & \\
\hline & South & -0.605 & 0.26 & $* *$ \\
\hline & Northeast & -0.787 & 0.272 & $* * *$ \\
\hline & North central & -0.515 & 0.193 & $* *$ \\
\hline & Rural & 0.776 & 0.232 & $* * *$ \\
\hline & Work & 1.514 & 0.202 & $* * *$ \\
\hline & Not Married & 0.117 & 0.303 & \\
\hline & In college & -0.731 & 0.149 & $* * *$ \\
\hline & College dropout & 0.432 & 0.332 & \\
\hline & College graduate & 0.634 & 0.359 & $* *$ \\
\hline & Economic self-efficacy & 0.03 & 0.01 & $* *$ \\
\hline & Money management & 0.128 & 0.013 & $* * *$ \\
\hline & Problem solving & 0.103 & 0.028 & $* * *$ \\
\hline \multirow[t]{4}{*}{ Parental Communication } & Close to mother & -0.042 & 0.075 & \\
\hline & Close to father & 0.029 & 0.014 & $*$ \\
\hline & Father communication & 0.055 & 0.075 & \\
\hline & Mother communication & 0.017 & 0.023 & \\
\hline \multirow[t]{8}{*}{ Parental socioeconomic } & Mother education & 0.153 & 0.042 & $* *$ \\
\hline & Father education & 0.003 & 0.026 & \\
\hline & Log Fam. Fin help & -0.133 & 0.038 & $* * *$ \\
\hline & Parental stock & -0.496 & 0.132 & $* * *$ \\
\hline & Log parental wealth & -0.035 & 0.028 & \\
\hline & Log parental debt & 0.022 & 0.055 & \\
\hline & Food stamp participation & 0.058 & 0.614 & \\
\hline & Log family income & -0.143 & 0.024 & $* * *$ \\
\hline
\end{tabular}

$\mathrm{N}=1432$

Peudo $R^{2}=0.4123$

$* \mathrm{p}<0.10 .{ }^{*} \mathrm{p}<0.01 . * * * \mathrm{p}<0.001$. 
Table 4: Financial Independence by Educational Attainment Status: Logit Regression Results

\begin{tabular}{|c|c|c|c|c|c|c|c|c|c|c|c|c|c|}
\hline \multirow[b]{2}{*}{ Category } & \multirow[b]{2}{*}{ Variables } & \multicolumn{3}{|c|}{ In College } & \multicolumn{3}{|c|}{ Never Attend } & \multicolumn{3}{|c|}{ Dropout } & \multicolumn{3}{|c|}{ Graduate } \\
\hline & & $\beta$ & SD & $\mathrm{p}$ & $\beta$ & SD & $\mathrm{p}$ & $\beta$ & SD & $\mathrm{p}$ & $\beta$ & SD & $\mathrm{p}$ \\
\hline \multirow[t]{16}{*}{$\begin{array}{l}\text { Child } \\
\text { characteristics }\end{array}$} & Age & 0.392 & 0.014 & $* * *$ & 0.269 & 0.05 & $* * *$ & 0.118 & 0.089 & & 0.496 & 0.269 & $*$ \\
\hline & Female & -0.593 & 0.194 & $* * *$ & -0.295 & 0.209 & & -0.495 & 0.241 & $*$ & 1.144 & 0.617 & $*$ \\
\hline & White & -0.119 & 0.181 & & -0.605 & 0.248 & $* *$ & 0.962 & 0.391 & $* *$ & 2.401 & 1.096 & $*$ \\
\hline & Log personal income & 0.143 & 0.045 & $* * *$ & 0.031 & 0.026 & & 0.008 & 0.041 & & 0.14 & 0.068 & $*$ \\
\hline & Lot personal asset & 0.153 & 0.035 & $* * *$ & 0.051 & 0.028 & $* *$ & 0.094 & 0.045 & $*$ & 0.021 & 0.139 & \\
\hline & Live with parents & -1.435 & 0.227 & $* * *$ & -0.446 & 0.236 & $*$ & -0.611 & 0.349 & $*$ & -1.969 & 0.823 & $* *$ \\
\hline & SAT math & 0.0105 & 0.111 & & & & & 0.005 & 0.047 & & 0.007 & 0.174 & \\
\hline & South & -0.396 & 0.018 & $*$ & -0.436 & 0.319 & & -0.2 & 0.386 & & -0.775 & 0.759 & \\
\hline & Northeast & -0.401 & 0.043 & $* * *$ & -0.103 & 0.337 & & 0.058 & 0.692 & & -1.046 & 0.867 & \\
\hline & North central & -0.386 & 0.019 & $* * *$ & -0.628 & 0.224 & $* *$ & -0.165 & 0.459 & & -0.705 & 0.852 & \\
\hline & Rural & 0.602 & 0.355 & $*$ & 2.488 & 0.343 & $* * *$ & 1.024 & 0.521 & $*$ & 1.858 & 1.007 & $*$ \\
\hline & Work & 1.198 & 0.224 & $* * *$ & 0.937 & 0.221 & $* * *$ & 0.708 & 0.364 & $*$ & 3.351 & 0.878 & $\begin{array}{l}* * \\
*\end{array}$ \\
\hline & Not married & -0.431 & 0.114 & $* * *$ & -0.576 & 0.29 & $*$ & 0.937 & 0.434 & $* *$ & 0.295 & 0.848 & \\
\hline & Economic self-efficacy & 0.028 & 0.025 & & 0.044 & 0.021 & $*$ & 0.029 & 0.343 & & 0.145 & 0.067 & $*$ \\
\hline & Money management & 0.134 & 0.044 & $* * *$ & 0.086 & 0.029 & $* *$ & -0.005 & 0.052 & & 0.018 & 0.09 & \\
\hline & Problem solving & 0.145 & 0.183 & & 0.045 & 0.035 & & 1.062 & 0.432 & $* *$ & 0.428 & 0.429 & \\
\hline \multirow[t]{4}{*}{$\begin{array}{l}\text { Parental } \\
\text { Communication }\end{array}$} & Close to mother & -0.156 & 0.161 & & -0.029 & 0.076 & & -0.023 & 0.131 & & -0.205 & 0.247 & \\
\hline & Close to father & 0.183 & 0.158 & & 0.031 & 0.07 & & 0.079 & 0.11 & & -0.21 & 0.291 & \\
\hline & Father communication & 0.301 & 0.324 & & 0.031 & 0.024 & & 0.004 & 0.037 & & 0.155 & 0.066 & $*$ \\
\hline & Mother communication & 0.113 & 0.294 & & 0.023 & 0.022 & & 0.005 & 0.034 & & -0.1 & 0.045 & $*$ \\
\hline \multirow[t]{8}{*}{$\begin{array}{l}\text { Parental } \\
\text { socioeconomic }\end{array}$} & Mother education & 0.065 & 0.054 & & 0.091 & 0.057 & & 0.006 & 0.087 & & 0.063 & 0.182 & \\
\hline & Father education & 0.084 & 0.029 & $*$ & -0.001 & 0.056 & & -0.049 & 0.086 & & -0.039 & 0.158 & \\
\hline & Parental stock & -0.556 & 0.164 & $* * *$ & -0.506 & 0.495 & & -1.322 & 0.849 & & -0.176 & 0.079 & $*$ \\
\hline & Log parental assets & -0.175 & 0.114 & & 0.01 & 0.032 & & 0.01 & 0.046 & & -0.301 & 0.147 & $*$ \\
\hline & Log parental debt & 0.028 & 0.052 & & 0.068 & 0.069 & & 0.074 & 0.108 & & -0.027 & 0.081 & \\
\hline & Food stamp participation & 0.583 & 0.486 & & 0.145 & 0.639 & & 1.368 & 0.348 & $* *$ & 1.173 & 0.834 & \\
\hline & Log Fam. Fin help & -0.189 & 0.028 & $* * *$ & -0.024 & 0.034 & & -0.249 & 0.05 & $* *$ & -0.185 & 0.629 & \\
\hline & Log parental income & -0.167 & 0.074 & $* *$ & -0.156 & 0.14 & & -0.163 & 0.196 & & 0.428 & 0.394 & \\
\hline $\mathrm{N}$ & & 587 & & & 473 & & & 248 & & & 124 & & \\
\hline Pseudo $\mathrm{R}^{2}$ & & 0.169 & & & 0.311 & & & 0.323 & & & 0.273 & & \\
\hline
\end{tabular}

